Case Report

\title{
Miescher's cheilitis: A case report with literature review
}

\author{
Adhikari Ram Chandra ${ }^{1}$, Shah Mahesh ${ }^{2}$ \\ ${ }^{1}$ Department of Pathology, Tribhuvan University Teaching Hospital, Kathmandu, Nepal. \\ ${ }^{2}$ Consultant Dermatologist, Anandban Leprosy Hospital, Lalitpur, Nepal.
}

\section{Keywords:}

Cheilitis;

Lip;

Melkersson-

Rosenthal syndrome;

Miescher's;

\begin{abstract}
Miescher's cheilitis is an inflammatory disorder characterized by chronic lip swelling due to granulomatous inflammation. It is rare disorder first described by Miescher in 1945. It is monosymptomatic form of Melkersson-Rosenthal syndrome. We report a case of Miescher's cheilitis in a 59-year old lady presented with recurrent swelling and erythema of upper lip and submental area with no features of facial palsy and fissuring of tongue. Laboratory tests including serum complement C3, C4 and C1 esterase inhibitor functional were within normal limits. The biopsy from the upper lip revealed dermal edema, dilated lymphatic channels and multiple granulomas. After exclusion of other causes of orofacial granulomatosis, the diagnosis of Miescher's cheilitis was made. Patient was treated with oral hydroxychloroquine and topical tacrolimus and mometasone cream with gradual improvement.
\end{abstract}

\section{Correspondence:}

Ram Chandra Adhikari, MD

Consultant Pathologist, Department of Pathology,

Tribhuvan University Teaching Hospital, Maharajgunj, Kathmandu, Nepal GPO Box no. 2496

Email: rcadhikari@hotmail.com

ORCID ID: 0000-0002-1605-2898

Reveived :October 25 $5^{\text {th }} 2017$; Accepted : December 6 ${ }^{\text {th }} 2017$; Published : March $30^{\text {th }} 2018$

Citation : Adhikari RC, Shah M. Miescher's cheilitis: A case report with literature review. J Pathol Nep 2018;8: 1313-6. doi: 3126/jpn.v8i1.19465

Copyright: This is an open-access article distributed under the terms of the Creative Commons Attribution 4.0 International License, which permits unrestricted use, distribution, and reproduction in any medium, provided the original author and source are credited.

\section{INTRODUCTION}

Miescher's cheilitis (MC) is a rare condition, also known as cheilitis granulomatosa (CG), characterized by recurrent lip swelling. This inflammatory disorder was first described by Miescher in 1945..$^{1,2}$ It is monosymptomatic form of Melkersson-Rosenthal syndrome (MRS), which is characterized by edema of the lips, facial palsy and fissuring of the tongue. MC is a granulomatous inflammatory disorder and an entity included under the umbrella of orofacial granulomatosis $(\mathrm{OFG})$, which was coined by Wiesenfeld in 1985. ${ }^{3}$ Here, we report a case of Miescher's cheilitis due to its rarity. 


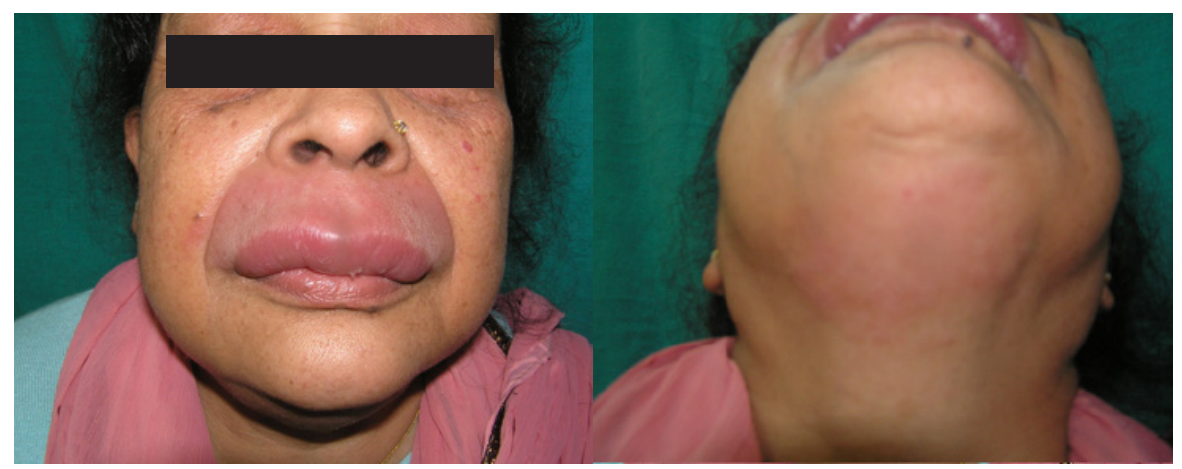

Figure 1A. Patient with erythema and swelling of upper lip. B. Same patient with erythema and swelling of submental area. (Informed consent was obtained from the patient for photographs)

\section{CASE REPORT}

A 59-year old lady presented with recurrent non-painful swelling and erythema of upper lip (fig.1A) and submental area (fig.1B) since 2 years, previously treated with intralesional and topical steroid. There was no history of cutaneous or systemic allergic manifestation or any other systemic disease. Features of facial palsy and fissuring of tongue were not present. On examination, the upper lip showed erythema and swelling with focal crusting. Submental area also showed erythema and mild swelling. Such lesions were not seen intraorally.

Ultrasonography revealed tortuous labial vessels and soft tissue thickening in upper lip and edematous thickening of subcutaneous tissue in submental region.

Laboratory examination revealed complete blood count within normal limits. No eosinophilia noted. Serological investigations for HIV, HBsAg, Anti-HCV, CRP and anti dsDNA were negative. Serum complement C3, C4 and C1 esterase inhibitor functional were within normal limits. Fine needle aspiration cytology of the lip was reported as inflammatory lesion. Provisional diagnoses of angioedema, cheilitis granulomatosa, leprosy and tuberculosis were made and punch biopsy from upper lip was taken.

The biopsy from the upper lip revealed dermal edema, dilated lymphatic channels (fig.2) and multiple granulomas with Langhans' type multinucleated giant cells (fig.3).

Ziehl-Neelsen stain and modified Fite stain for acid fast bacilli were negative. PAS stain did not reveal any fungal elements. Congo red was negative for amyloid. PCR for mycobacterial DNA and immunohistochemistry for mycobacteria were negative. Immunohistochemistry for Leishmania was also negative. With all of these findings the diagnosis of Miescher's cheilitis was made.

Patient was treated with oral hydroxychloroquine sulfate
$200 \mathrm{mg}$ once daily and topical tacrolimus and mometasone cream. After 2 months of treatment, submental swelling and erythema disappeared completely and lip swelling was still persisting but with significant improvement.

\section{DISCUSSION}

Miescher's cheilitis is a rare disease with unknown etiopathogenesis and the swelling of lip due to granulomatous inflammation. It is a monosymptomatic form of MelkerssonRosenthal syndrome, which is characterized by the triad of orofacial edema, facial palsy and fissured tongue. The complete triad is present in $8 \%$ to $25 \%$ of patients diagnosed with MRS, while oligosymptomatic forms of the condition account for $47 \%$ of cases. ${ }^{4}$ Miescher's cheilitis is the most common form of MRS constituting $80 \%$ of cases. ${ }^{5,6}$ Our patient had monosymptomatic form of the syndrome without facial palsy and fissured tongue. No neurological signs were present in our patient.

In 1985, Wiesenfeld et $\mathrm{al}^{3}$ coined the concept of orofacial granulomatosis to describe a series of non-infectious, non-necrotizing granulomatous disorders of the lips, face and oral cavity that included CG, Crohn's disease and sarcoidosis. OFG is an umbrella term that encompasses a number of entities of diverse etiology, pathogenesis and clinical features.

The etiology of MC is poorly understood, but has been associated with genetic ${ }^{7}$, allergic ${ }^{8}$, and infectious ${ }^{9}$ factors. Some cases may demonstrate an autosomal dominant inheritance pattern, with the responsible gene mapping to chromosome 9p11. ${ }^{7}$ There are reports that associate the pathogenesis of MC with odontogenic infection ${ }^{4,9}$ and autoimmune mechanism. ${ }^{9}$ Authors even mentioned that the episode of MC persists even after the infection has resolved in some patients. ${ }^{4}$ Various food items including chocolate, food additives and cinnamon compounds have been implicated as possible etiologic agents; the elimination of these items from food have led to improvement in 


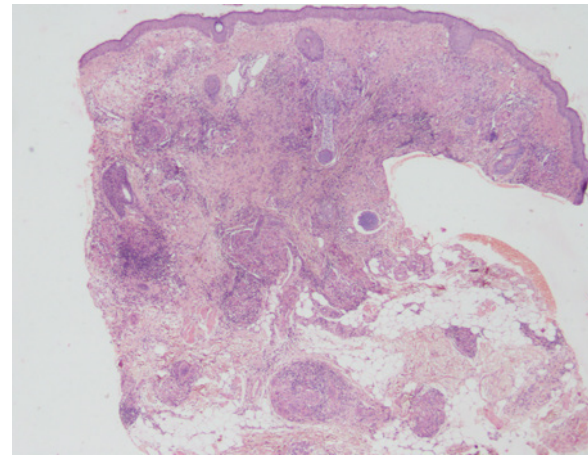

Figure 2: Upper lip biopsy: Low power view showing dilated lymphatic channels in the upper dermis and granuloma in the lower dermis (HE stain; X40).

some patients. ${ }^{10,11}$ Sensitization to metals such as gold and mercury has also been linked to this disease. ${ }^{12}$

Miescher's cheilitis occurs most frequently in the second or third decade of life, but can occur at any age with no racial or sexual predilection. ${ }^{2}$ In a study of Martinez Martinez ML et al, the age of patients with MC ranged between 29 and 74 years. ${ }^{4}$ Our patient was 59 -year-old female.

Histopathological findings of MC include dermal noncaseating granuloma, dermal edema and dilatation of lymphatic channels. The overlying epidermis is usually hyperplastic. There is no acanthosis of epidermis in our case and all other histological features were present.

Differential diagnoses of $\mathrm{MC}$ include mycobacterial infection, foreign body reaction, sarcoidosis, Crohn's disease, Wegener's granulomatosis, histoplasmosis, amyloidosis, rosacea, medications such as ACE inhibitors and calcium channel blockers; atopic reactions to a wide variety of allergens and hereditary diseases such as $\mathrm{C} 1$ esterase deficiency. ${ }^{13}$ In our case, we have excluded mycobacterial infection, amyloidosis, fungal infection and $\mathrm{C} 1$ esterase deficiency by special stains, EIA, PCR or immunohistochemistry. Features of vasculitis were not present excluding the possibility of Wegener's granulomatosis. History of intake of ACE inhibitors or calcium channel blockers was not found in our case. Crohn's disease is difficult to rule out based on morphology, however Crohn's disease is more likely to involve the oral cavity and in our patient, no lesions were noted in oral cavity. In addition, there has been an association noted between MC and Crohn's disease. ${ }^{14}$

In patients presenting with lip swelling, it is important to perform an appropriate evaluation, which includes history of atopy or current therapy with an ACE inhibitor or calcium channel blocker, chest X-ray and mantoux test to exclude angioedema, sarcoidosis or mycobacterial

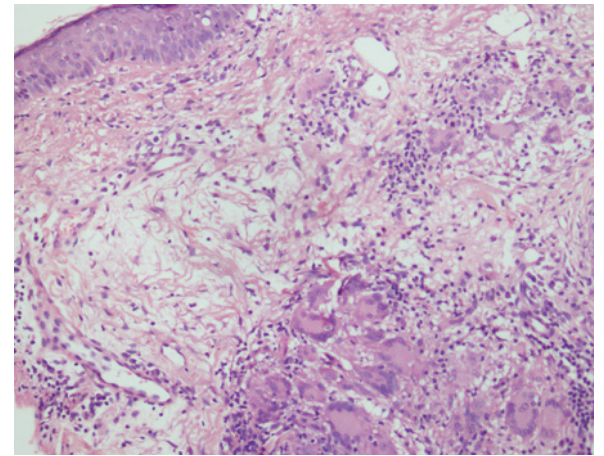

Figure 3: Upper lip biopsy: Closer view showing dermal edema and granuloma with Langhans'type multinucleated giant cells (HE stain; X200).

infection. Gastrointestinal tract endoscopy may exclude Crohn's disease. A family history of orofacial swelling should prompt an investigation into the autosomal dominant C1 esterase inhibitor deficiency (hereditary angioedema). Patch test or serum allergy test shall be used to rule out food and food additives sensitivity.

There is no definite treatment for $\mathrm{MC}$ as the pathogenesis is obscure. White $\mathrm{A}$ et $\mathrm{al}^{15}$ recommended a cinnamonand benzoate-free diet as first line therapy for OFG as lip inflammatory score goes down at 8 weeks. Various other treatment options for MC have been reported including antibiotics like tetracycline, roxithromycin and clofazimine $^{16}$, metronidazole ${ }^{13}$, hydroxychloroquine ${ }^{17}$, oral and intralesional steroids ${ }^{13,18}$, adalimumab (TNF alpha inhibitor $)^{13}$ and surgical resection. ${ }^{19}$

\section{CONCLUSION}

Miescher's cheilitis is an independent entity within the group of orofacial granulomatosis. It is rare and difficult to diagnose and treat. In this case, the diagnosis of MC was made after exclusion of other causes of OFG and importance of thorough investigation is highlighted.

\section{Conflict of Interest: None}

\section{REFERENCES}

1. Worsaae N, Christensen KC, Schiodt M, Reibel J. MelkerssonRosenthal syndrome and cheilitis granulomatosa. A clinicopathological study of thirty-three patients with special reference to their oral lesions. Oral Surg Oral Med oral Pathol 1982;54:404-13. Crossref

2. Van der Waal RI, Schulten EA, van der Scheur MR, Wauters IM, Starink TM, van der Waal I. Cheilitis granulomatosa. J Eur Acad Dermatol Venereol 2001;15:519-23. Crossref

3. Wiesenfeld D, Ferguson MM, Mitchell DN, MacDonald DG, Scully C, Cochran K et al. Oro-facial granulomatosis: A clinical and pathological analysis. Q J Med 1985;54:101-3. Crossref 
4. Martinez Martinez ML, Azana-Defez JM, Perez-Garcia LJ, Lopez-Villaescusa MT, Rodriguez Vazquez M, Faura Berruga C. Granulomatous cheilitis: A report of 6 cases and a review of the literature. Actas Dermosifilliogr 2012;103:718-24. Crossref

5. Greene RM, Rogers III RS. Melkersson-Rosenthal syndrome: A review of 36 patients. J Am Acad Dermatol 1989;21:1263-70. Crossref

6. Worsaae N, Christensen KC, Schiodt M, Reibel J. MelkerssonRosenthal syndrome and cheilitis granulomatosa. A clinicopathologic study of thirty-three patients with special reference to their oral lesions. Oral Surg Oral Med Oral Pathol 1982;54:404-13. Crossref

7. Smeets E, Fryns JP, Van den Berghe H. Melkersson-Rosenthal syndrome and de novo autosomal $\mathrm{t}(9 ; 21)$ (p11;p11) translocation. Clin Genet 1994;45:323-4. Crossref

8. Vibhute NA, Vibhute AH, Daule NR. Cheilitis granulomatosa: A case report with review of literature. Indian J Dermatol 2013;58:242. Crossref

9. Muellegger RR, Weger W, Zoechling N, Kaddu S, Soyer HP, EI Shabrawi-Caelen L. Granulomatous cheilitis and Borrelia burgdorferi: Polymerase chain reaction and serologic studies in a retrospective case series of 12 patients. Arch Dermatol 2000;136:1502-6. Crossref

10. Mc Kenna KE, Walsh MY, Burrows D. The Melkersson-Rosenthal syndrome and food additive hypersensitivity. $\mathrm{Br} \mathrm{J}$ Dermatol 1994;131:921-2. Crossref

11. Fitzpatrick L, Healy CM, McCartan BE, Flint SR, McCreary CE, Rogers S. Patch testing for food-associated allergies in orofacial granulomatosis. J Oral Pathol Med 2011;40:10-3. Crossref
12. Lazarov A, Kidron D, Tulchinsky Z, Minkow B. Contact orofacial granulomatosis caused by delayed hypersensitivity to gold and mercury. J Am Acad Dermatol 2003;49:1017-20. Crossref

13. Critchlow WA, Chang D. Cheilitis granulomatosa: A review. Head Neck Pathol 2014;8:209-13. Crossref

14. Van der Waal RI, Schulten EA, van der Meij EH, van de Scheur MR, Starink TM, van der Waal I. Cheilitis granulomatosa: Overview of 13 patients with long-term follow-up results of management. Int J Dermatol 2002;41:225-9. Crossref

15. White A, Nunes C, Escudier M, Lomer MC, Barnard K, Shirlaw $\mathrm{P}$, Challacombe SJ, Sanderson JD. Improvement in orofacial granulomatosis on a cinnamon- and benzoate-free diet. Inflamm Bowel Dis 2006;12:508-14. Crossref

16. Inui S, Itami S, Katayama I. Granulomatous cheilitis successfully treated with roxithromycin. J Dermatol 2008;35:244-5. Crossref

17. Allen CM, Camisa C, Hamzeh S, Stephens L. Cheilitis granulomatosa: report of 6 cases and review of literature. J Am Acad Dermatol 1990;23:444-50. Crossref

18. Bacci C, Valente ML. Successful treatment of cheilitis granulomatosa with intralesional injection of triamcinolone. J Eur Acad Dermatol Venereol 2010;24:363-4. Crossref

19. Mori F, Ciancio F, De Giorgi V, Parronchi P, Vultaggio A, Matucci A. Miescher's cheilitis: Surgical management and long term outcome of an extremely severe case. Int J Surg Case Rep 2017;31:241-4. $\underline{\text { Crossref }}$ 